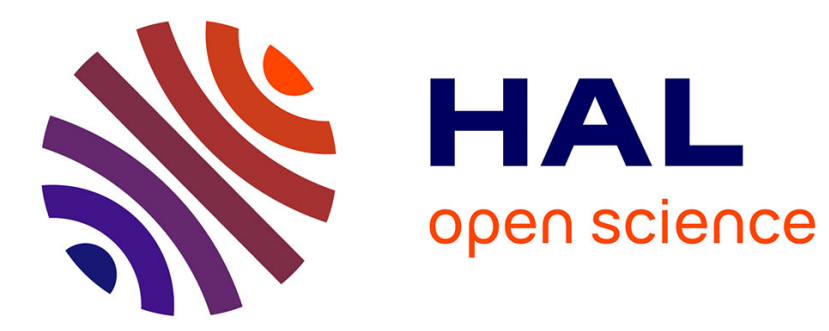

\title{
TEMPERATURE DEPENDENCE OF THE EXTRAORDINARY HALL EFFECT IN AMORPHOUS ( FeCoNi)78B12Si10 ALLOYS
}

\author{
J. Ivkov, E. Babić, Z. Marković
}

\section{> To cite this version:}

J. Ivkov, E. Babić, Z. Marković. TEMPERATURE DEPENDENCE OF THE EXTRAORDINARY HALL EFFECT IN AMORPHOUS ( FeCoNi)78B12Si10 ALLOYS. Journal de Physique Colloques, 1988, 49 (C8), pp.C8-1301-C8-1302. 10.1051/jphyscol:19888593 . jpa-00228815

\section{HAL Id: jpa-00228815 https://hal.science/jpa-00228815}

Submitted on 1 Jan 1988

HAL is a multi-disciplinary open access archive for the deposit and dissemination of scientific research documents, whether they are published or not. The documents may come from teaching and research institutions in France or abroad, or from public or private research centers.
L'archive ouverte pluridisciplinaire $\mathbf{H A L}$, est destinée au dépôt et à la diffusion de documents scientifiques de niveau recherche, publiés ou non, émanant des établissements d'enseignement et de recherche français ou étrangers, des laboratoires publics ou privés. 


\title{
TEMPERATURE DEPENDENCE OF THE EXTRAORDINARY HALL EFFECT IN AMORPHOUS (FeCoNi) ${ }_{78} \mathbf{B}_{12} \mathrm{Si}_{10}$ ALLOYS
}

\author{
J. Ivkov, E. Babić ${ }^{1}$ and Z. Marković ${ }^{2}$ \\ Institute of Physics of the University, POB 304, Bienička 46, 41001 Zagreb, Yugoslavia
}

\begin{abstract}
Temperature dependences of the extraordinary Hall coeficient $R_{\mathrm{s}}$ and resistivity $\rho$, yield $R_{\mathrm{s}} \sim \rho^{2}$ (arising from the side-jump mechanism) for the majority of investigated FeCoNi-based alloys. The deviation from $\rho^{2}$ variation in Co-rich alloys is probably due to the temperature dependence of the magnetic anisotropy in these alloys.
\end{abstract}

One of the characteristic features of amorphous ferromagnetic alloys, as compared to the crystalline ones, is large extraordinary Hall effect. This is a direct consequence of the high resistivity $\rho$ of these alloys. It is generally accepted $[1,2]$ that in strongly disordered transition metal alloys the main contribution to the extraordinary Hall effect comes from the sidejump mechanism [3] that leads to the $\rho^{2}$ dependence of the extraordinary Hall coefficient $R_{s}$. The experimental confirmation of this dependence is somewhat difficult in amorphous alloys because their resistivity, that is already large, changes only slightly with temperature, and the same holds for $R_{s}$ too. Therefore very accurate determination of $R_{\mathrm{s}}$ is required in order to deduce the correlation between $R_{B}$ and $\rho$. Here we report this correlation for amorphous $\mathrm{Fe}_{x} \mathrm{Ni}_{78-x} \mathrm{~B}_{12} \mathrm{Si}_{10}$, $\mathrm{Fe}_{x} \mathrm{Co}_{78-x} \mathrm{~B}_{12} \mathrm{Si}_{10}$ and $\mathrm{Co}_{x} \mathrm{Ni}_{78-x} \mathrm{~B}_{12} \mathrm{Si}_{10}$ alloys. All our alloys are ferromagnetic with the Curie temperature $T_{c}$ above $420 \mathrm{~K}$ except for $\mathrm{Fe}_{23} \mathrm{Ni}_{55} \mathrm{~B}_{12} \mathrm{Si}_{10}$ and $\mathrm{Co}_{39} \mathrm{Ni}_{39} \mathrm{~B}_{12} \mathrm{Si}_{10}$ alloys $\left(T_{\mathrm{c}}=410\right.$ and $390 \mathrm{~K}$ respectively).

The Hall resistivity $\rho_{\mathrm{H}}$ (in magnetic field up to $1 \mathrm{~T}$ ) and electrical resistivity have been measured from 77 to $420 \mathrm{~K}$. The details concerning the sample preparation and the measurement technique were reported earlier $[4,5]$. The temperature variations of the resistivity were reported in reference [6]. The rather small cross section of our samples (typically $0.8 \times 0.018 \mathrm{~mm}^{2}$ ) resulted in an uncertainty of about $10 \%$ in the absolute value of $\rho_{\mathrm{H}}$.

The initial slopes of the Hall resistivity as a function of magnetic field $R_{H}=\left(\Delta \rho_{H} / \Delta B\right)_{B=0}$ for all our alloys are of the order $10^{-8} \mathrm{~m}^{3} \mathrm{~A}^{-1} \mathrm{~s}^{-1}$. At the same time the normal Hall coefficient $R_{0}$ of the amorphous alloys is equal to or lower than the free electron value and is practically temperature independent. For our alloy systems $R_{0}$ is of the order $10^{-10} \mathrm{~m}^{3} \mathrm{~A}^{-1} \mathrm{~s}^{-1}$ and therefore we neglect its contribution to $R_{\mathrm{H}}$. Hence $R_{\mathrm{H}}$ is practically equal to $R_{s}\left(\mu_{0} \Delta M / \Delta B\right)_{B=0}$ where $M$ is the magnetization of the sample. In the case of a thin Hall sample and isotropic material $R_{\mathrm{H}}$ is then equal to the extraordinary Hall coefficient $R_{3}$.

The concentration dependence of $R_{s}$ for our alloys at room temperature is shown in figure 1. The data for amorphous $\mathrm{Fe}_{x} \mathrm{Ni}_{80-x} \mathrm{~B}_{18} \mathrm{Si}_{2}$ alloys from references $[4,5]$ are included in the same figure. We note a similar size and practically the same concentration dependence of $R_{s}$ in two FeNi-based systems. The variation of $R_{s}$ with $x$ in FeCo-based alloys is also similar to that observed for homogeneous ferromagnetic FeNibased alloys $(x \geq 15)$. For ferromagnetic CoNi-based alloys we have not enough data to deduce the variation of $R_{s}$ with $x$ in this system. It would be misleading to correlate $R_{s}$ and $\rho$ values for different alloys because the differences in the band structure may influence $R_{s}$ more than the resistivity does [3]. Therefore one has to investigate the temperature variations of $\rho$ and $R_{s}$ in order to deduce the actual dependence of $R_{3}$ on $\rho$.

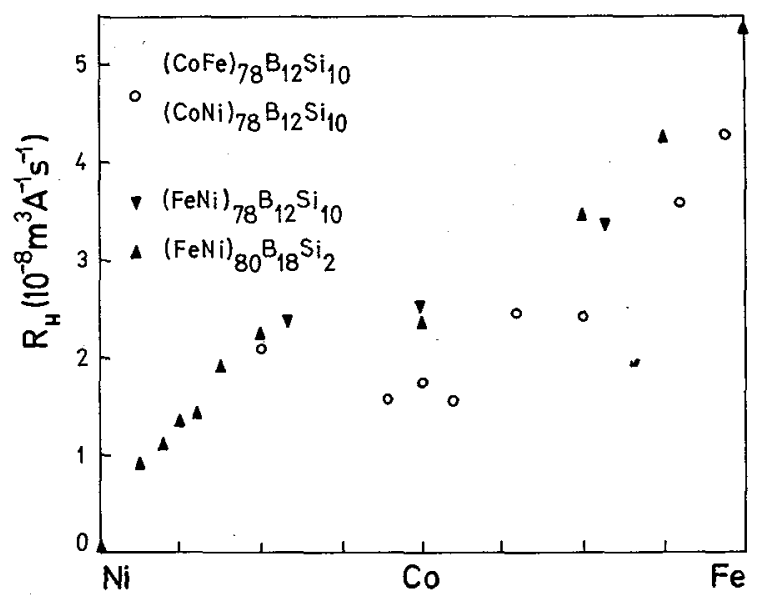

Fig. 1. - Concentration dependence of $R_{\mathrm{H}}$ in FeCoNi-based alloys.

\footnotetext{
${ }^{1}$ Departement of Physics, Faculty of Science, Zagreb, Yugoslavia.

${ }^{2}$ Institute "Rudjer Bošković", Zagreb, Yugoslavia.
} 
The temperature dependence of $R_{\mathrm{s}}$ in four alloys is shown in figure 2. A continuous increase of $R_{s}$ with temperature was observed for all alloys. We note that the relative change of $R_{\mathrm{B}}$ in the temperature inteval from 77 to $420 \mathrm{~K}$ is ranging from 10 to $15 \%$ only. The behaviour of $R_{\mathrm{a}}$ in $\mathrm{Fe}_{23} \mathrm{Ni}_{55} \mathrm{~B}_{12} \mathrm{Si}_{10}$ and $\mathrm{Co}_{39} \mathrm{Ni}_{39} \mathrm{~B}_{12} \mathrm{Si}_{10}$ alloys as well as our previous data $[4,5]$ indicate that the extraordinary Hall coefficient does not change on passing through $T_{\mathrm{c}}$. We consider that such behaviour of $\boldsymbol{R}_{\mathbf{s}}$ is characteristic for FeCoNibased amorphous alloys and possibly extends to other amorphous ferromagnets as well.

In order to obtain the correlation between $R_{s}$ and $\rho$ we plotted $\ln \left(R_{\mathrm{s}}(T) / R_{\mathrm{s}}(77 \mathrm{~K})\right)$ vs. $\ln (\rho(T) / \rho(77 \mathrm{~K}))$ and the results for three alloys are presented in figure 3 . We note that the correlation systematically depends on the concentration of the alloys. In most of FeCoNi alloys $R_{s}$ varies, through the explored temperature interval, as the square of the resistivity as predicted by theory [3]. In Co-rich alloys $R_{\mathrm{s}}$ increases with temperature significantly faster than $\rho^{2}$ and cannot be described by a single power law of $\rho$. However the deviation from the predicted $\rho^{2}$ dependence becomes smaller with increasing temperature and in the case of $\mathrm{Co}_{39} \mathrm{Ni}_{39} \mathrm{~B}_{12} \mathrm{Si}_{12}$ alloy (Fig. 3) $R_{\mathrm{s}}$ varies almost as $\rho^{2}$ when temperature approaches $T_{\mathrm{c}}$. The observed behaviour indicates that the assumptions of the same temperature dependence and equality between $R_{\mathrm{s}}$ and $R_{\mathrm{H}}$ may not be quite correct for Co-rich alloys. Although we have no detailed explanation for this observation we note that for magnetically anisotropic material $\left(\mu_{0} \Delta M / \Delta B\right)_{B=0}$ value is expected to be different from unity and temperature dependent. Even small temperature variation of $\left(\mu_{0} \Delta M / \Delta B\right)_{B=0}$ values can influence the determination of the actual $R_{\mathrm{s}}$ values from the $\rho_{\mathrm{H}}$ data only. In this case in order to obtain the exact correlation between $R_{\mathrm{B}}$ and $\rho$ a detailed knowledge of the temperature and field dependences of magnetization is required.

In conclusion, an average $\rho^{2}$ dependence of $R_{s}$ (consistent with the side-jump mechanism [3]) has been obtained for the majority of amorphous $\mathrm{FeCoNi}$-based alloys. For Co-rich alloys $R_{s} v s$. $\rho$ dependence cannot be described by a single power law. This behaviour is tentatively ascribed to the temperature dependence of the magnetic anisotropy which affects the determination of actual $R_{\mathrm{s}}$ values.

[1] Hurd, C. M., J. Appl. Phys. 50 (1979) 7526.

[2] McGuire, T. R., Gambino, R. J. and O'Handley, R. C., The Hall Effect and its Applications, Eds. C. L. Chien and C. R. Wf (New York, Plenum) 1980.

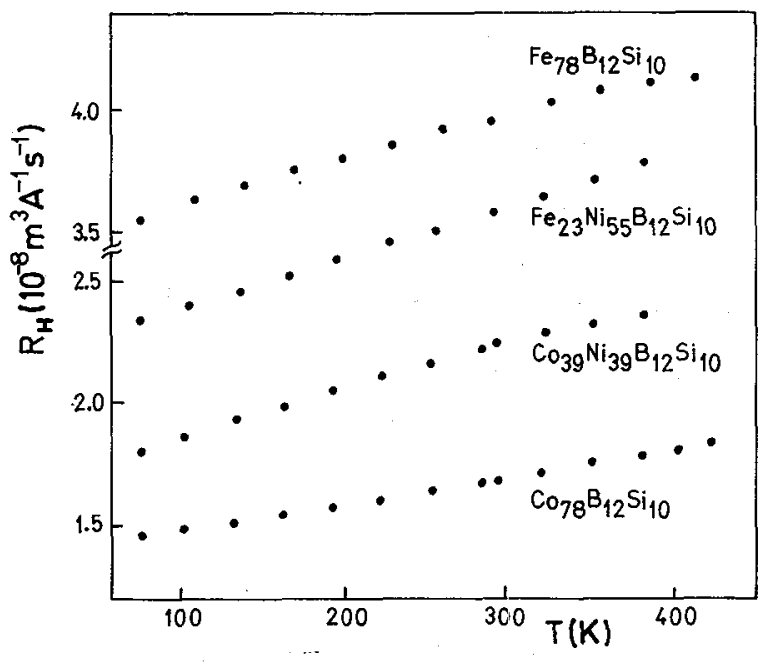

Fig. 2. - Variation of $R_{\mathrm{H}}$ with temperature for four alloys.

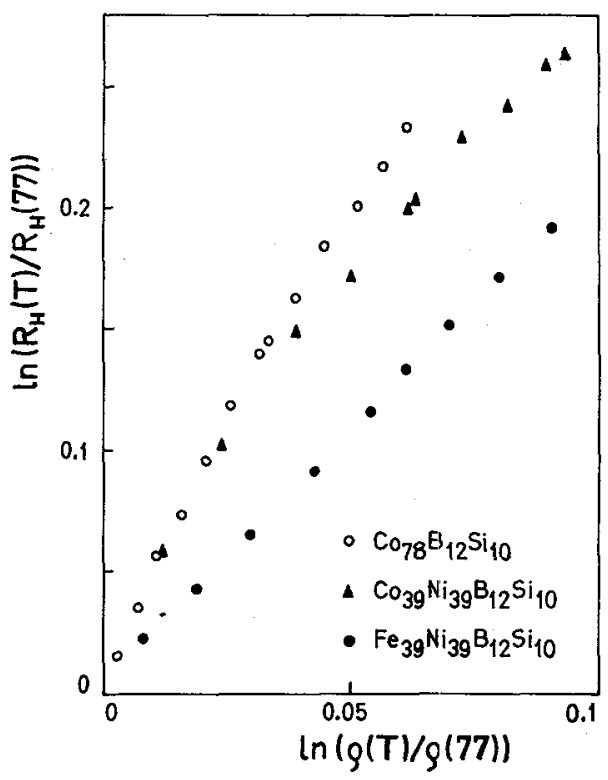

Fig. 3. $-\ln R_{\mathrm{H}} v s . \ln \rho$ variation for three alloys.

[3] Berger, L., Phys. Rev. B 2 (1970) 4559.

[4] Ivkov, J., Marohnić, Z., Babić, E.., Miljak, M. and Liebermann, H. H., J. Phys. F 13 (1983) 2173.

[5] Ivkov, J., Marohnić, Z., Babić, E. and Dubcek, P., J. Phys. F 14 (1984) 3023.

[6] Babić, E., Ocko, M., Marohnić, Z., Davies, H., A. and Donald. I. W., Proc. 4th Int. Conf. RQM, Eds. T. Masumoto and K. Suziaki (Japan Institute of Metal, Sendai) 1982, p. 857. 